JOURNAL OF HEALTH SCIENCE AND PREVENTION

http://jurnalfpk.uinsby.ac.id/index.php/jhsp

ISSN 2549-919X (e)

\title{
Effect of Foot Care Health Training Towards Nurses and Health Volunteers Ability in Performing Foot Care on Diabetes in Batua Health Center, Makassar
}

\author{
Elly Lilianty Sjattar1 , Abdul Majid¹, Saldy Yusuf', Yuliana Syam¹, Nurhaya Nurdin² \\ 1) Division of Medical Surgical Nursing, Faculty of Nursing, Universitas hasanuddin \\ 2) 2Division of Community Nursing, Faculty of Nursing, Universitas hasanuddin \\ ellyunhas@gmail.com \\ DOI: http://doi.org/10.29080/jhsp.v3i3S.275
}

\begin{tabular}{|c|c|}
\hline Kata Kunci & Abstrak \\
\hline $\begin{array}{l}\text { Foot Care; } \\
\text { Nurse; } \\
\text { Care Giver; } \\
\text { Diabetes } \\
\text { Mellitus; } \\
\text { Self-Care }\end{array}$ & $\begin{array}{l}\text { Foot care is one of the management for diabetes mellitus that is important to prevent } \\
\text { diabetes ulcers. Studies have proven that people with diabetes will have a lower risk of } \\
\text { having diabetes ulcer if they have received health education about foot care to prevent } \\
\text { diabetes ulcers Thus, health education is considered very important to help people with } \\
\text { diabetes preventing foot ulcer. Health care provider including health professionals and } \\
\text { health volunteers should provide health education regularly to the patient, however, due to } \\
\text { their workload preventing them from providing this intervention to the patient as well as } \\
\text { a lack of knowledge about foot care. Based on the initial interview with diabetes program } \\
\text { staff, the health education program is not implemented well yet and they need specific } \\
\text { training about foot care for nurses, health volunteers and patients. The aim of this study is } \\
\text { to see the effect of foot care health training towards nurses and health volunteers ability } \\
\text { performing foot care on diabetes. This study used pre-experimental with pre-test and post- } \\
\text { test one-group design to } 30 \text { respondents (23 health volunteers and } 7 \text { nurses from } \\
\text { Puskesmas Batua Makassar). The training was given the research team, and after } \\
\text { training, there was follow-up training (two times) where the research team accompanied } \\
\text { the respondents to provide foot care to the patients which was assessed through a } \\
\text { questionnaire. Data were analysed using the paired t-test.This study found there is an } \\
\text { improvement in ability in conducting diabetes foot care among the participants the } \\
\text { average before treatment( } x=17.93 \text {, SD } 1.363 \text { ) to (x }=19.37 \text {, SD } 0.718 \text { ) after training. } \\
\text { This study has proven the effect of training to improve nurses and health volunteers ability } \\
\text { in performing foot care on diabetes patient. Thus, it is recommeded that nurses and health } \\
\text { volunteers regularly providing health education related to foot care for diabetes patients } \\
\text { to prevent foot ulcer such as including it in Prolanis health education program. }\end{array}$ \\
\hline
\end{tabular}

\section{Introduction}

Diabetes is one of the health problems that have a bad impact if not treated. One of the long-term effects of untreated diabetes is the occurrence of foot injuries that lead to amputation (1). Before the occurrence of foot injuries in diabetic patients, it is usually preceded by some foot problems such as dry skin, hyperkeratosis, changes in a nail shape and foot shape (2). Therefore, prevention efforts are needed before the occurrence of diabetic foot injuries.

The prevalence of diabetes mellitus is expected to continue to increase. International Diabetes Federation (IDF) mentions that there are 134.6 million diabetic patients worldwide and is expected to increase to 252.8 million by 2035 (3). In Indonesia, especially in Sulawesi Island, South Sulawesi was the second highest ranks after North Sulawesi with 1.6\%. While at the district level, the prevalence of diabetes incidence for Makassar City was 2.5\%, North Toraja District 2.3\% and the highest was Pinrang District $2.8 \%$ (4). The prevalence of the risk of a foot injury in the Makassar region is also high (5) found that from 249 respondents, 112 of them were at risk of developing diabetic foot injuries with a percentage of $55.4 \%$ and CI 53.7\% - 57.0\%.

One of the fulfilment of needs of self-care in people with diabetes is to provide education about foot care to prevent the occurrence of diabetic foot injuries (6), especially in patients at risk for injury. Foot care is one type of diabetes mellitus management that is considered useful for the prevention of diabetic foot injuries. The International Working Group on the Diabetic Foot (IWGDF) states that education about foot 
care in patients at risk of foot injury has a much lower risk than patients who do not receive foot care education (7). Also, foot care education is the right nursing intervention in preventing more severe, painful and debilitating complications of diabetic patients (8).

Several studies have been conducted to assess the level of knowledge, self-efficacy and behaviour of foot care in preventing diabetes foot injury. Research conducted by Fan, Sidani, Cooper-Brathwaite, \& Metcalfe (2014) showed an increase in knowledge and self-efficacy related to foot care after being given an educational intervention (9). Also, researched educational programs for foot care. The results showed an increase in behaviour and self-efficacy of foot care (3).The same research was also carried out by Mahdalena \& Ningsih, the results obtained were an increase in knowledge about foot care, self-efficacy scores and an increase in foot care behaviour scores (10).

In 2017, Batua Health Center of Makassar City has managed DM sufferers as many as 40 people, and 8 of them suffered injuries to the foot area. The results of the interview with the person in charge of DM at Batua Health Center stated that there had never been any training and mentoring activities on foot care. This fact underlines the importance of increasing knowledge about diabetic foot care carried out to nurses who are responsible for managing people with diabetes at the health centre and health volunteers as the health team living in the vicinity of the residence of the person with diabetes.

\section{Methods}

Design of this study was pre-experimental with pre-test and post-test one group design involving 30 respondents consisting of 7 nurses and 23 health volunteers living in the working area of Batua Health Center, Makassar and for respondents selected purposively by criteria Inclusion are: (1) Care giver who are actively involved in Prolanis activities; (2) Care giver in the area around their homes are many DM sufferers (mapping results); (3) Nurses involved in Prolanis activities; (4) Nurses of health center who actively do home visit. The number of samples is based on the calculation of the sample size according to Cohen (1988), which amounts to a minimum of 30 samples.

The instrument to measure the self-care of nurses in performing foot care was developed from the results of the consensus Study Delphy (11). The number of questions is ten items with two answer choices, namely "Yes" and "No". The components of the questions on the instrument include: checking your feet and between your toes every day; wash your feet and between your toes; Drying the Feet and between the Toes After washing it is not necessary to wear a towel; use moisturizing cream when feet are dry; Cut toenails every week; how to cut toenails; how to use socks and footwear.

Before training program conducted, a pre-testis done first. The intervention was carried out for 3 weeks. 1stWeek, education was carried out in the form of foot care using a simulation method. 2nd Week, mentoring helath volunteers by identifying things that have been done and not done related to diabetic foot care, as well as recalling the foot care education material that has been given. 3rd Week, an evaluation of foot care was carried out using each respondent ability performing foot care on diabetesand observed, After that, a post-test was carried out using the same questionnaire as the pre-test. Data analysis was carried out by descriptive analysis, and the data were normally distributed, hence for inferential tests carried out using parametric analysis. The paired t-test is used to determine the difference in the self care of foot care before and after the intervention.

\section{Results}

Table 1. shows the majority of respondents aged in the range of 42-60 years (56.67\%), the most ethnic groups are Makassar (50\%), married (83.33\%), high school education (56.67\%), not working (73.33) and have no experience in caring for DM sufferers (76.67).

Table 1 Frequency Distribution of Characteristics of Foot Care Education Respondents in Nurses and Health Volunteers $(\mathrm{N}=30)$

\begin{tabular}{|c|c|c|c|c|c|c|}
\hline No & Variables & & $\mathrm{f}$ & $\%$ & Mean & SD \\
\hline \multirow[t]{3}{*}{1} & Age & & & & 41.6 & 9.79 \\
\hline & & 20 - 41 Year & 13 & 43.33 & & \\
\hline & & 42 - 60 Years & 17 & 56.67 & & \\
\hline \multirow[t]{5}{*}{2} & Tribe & & & & & \\
\hline & & Makassar & 15 & 50 & & \\
\hline & & Bugis & 12 & 40 & & \\
\hline & & Toraja & 2 & 3 & & \\
\hline & & Java & 1 & 7 & & \\
\hline \multirow[t]{2}{*}{3} & Unmarried & & & & & \\
\hline & & Marriage & 4 & 13.33 & & \\
\hline
\end{tabular}




\begin{tabular}{|c|c|c|c|c|}
\hline & & Married & 25 & 83.33 \\
\hline & & Widow & 1 & 7 \\
\hline \multirow[t]{4}{*}{4} & Education & & & \\
\hline & & $\begin{array}{l}\text { SMP (Junior High } \\
\text { School) }\end{array}$ & 4 & 13.33 \\
\hline & & $\begin{array}{l}\text { SMA (Senior High } \\
\text { School) }\end{array}$ & 17 & 56.67 \\
\hline & & $\begin{array}{l}\text { S1(Undergraduat } \\
\text { e) }\end{array}$ & 9 & 30 \\
\hline \multirow[t]{3}{*}{5} & Jobs & & & \\
\hline & & Not Working & 22 & 73.33 \\
\hline & & Work & 8 & 26.67 \\
\hline \multirow[t]{3}{*}{6} & Experience & aring for People wi & & \\
\hline & & Yes & 7 & 23.33 \\
\hline & & No & 23 & 76.67 \\
\hline
\end{tabular}

Table 2 Differences in the average ability in performing foot care on diabetes of nurses and health volunteers before and after foot care training $(\mathrm{N}=30)$

\begin{tabular}{lccc}
\hline \multicolumn{1}{c}{ Variable } & Mean (SD) & $\mathrm{T}$ & value $p$ \\
\hline & & & \\
Before & $17.93(1.36)$ & $-5,487$ & $0,000^{\mathrm{a}}$ \\
After & $19.37(0.72)$ & & \\
\hline
\end{tabular}

Table 2. explains the differences in the average ability in performing foot care on diabetes of nurses and health volunteers, before the foot care training intervention found a score (17.93 \pm 1.36$)$, and after the intervention experienced an increase in score to $(19.37 \pm 0.72)$. The test results paired $t$-test found a significant difference between before and after the intervention $(p=0.000)$.

\section{Discussion}

The results of this study indicate that the foot care training program significantly increases the ability of performing foot care on the diabetes of nurses and health volunteers. These results of the test prove these results before and after treatment. Several things support the of Nurses and health volunteers regarding diabetes foot care, including 1) A mentoring process accompanies this training program, 2) The method used is training, 3) Respondents who were actively involved both during the training process and mentoring process. The basis of the foot care training program is supported by the model of Self Care theory adapted from Orem (12). Based on the concept of the theory Self-care is formed by3 pillars, namely: Self-care demand, Self-care agency, and self-care deficit. If someone experiences an imbalance between Self-care demand and Self-care agency, then the person is declared self-care deficit and requires a nursing system. Orem herself divided the nursing system into three categories, are Wholly Compensatory, Partly Compensatory, and educative supportive. This concept model is often used to isolate patients in hospitals. Because this study took nurse respondents and caregiver, so the approach used in educative supportive methods where providing foot care training to nurses and health volunteers who are accompanied by assistance in the hope that they will become a health volunteers (Self-care agency) who will help people with diabetes mellitus in the work area to be able to perform foot care independently. Black \& Hawk explained that nurses are responsible for diabetic management, including assessment, education, and direct care and evaluation.

Education or training for people with diabetes is one of the efforts that can be done in preventing the occurrence of diabetic foot injuries (DFI). IWGDF recommends 13 components in efforts to prevent the occurrence of DFI, and one component is to educate people with DM who are at high risk to improve knowledge and behaviour of foot care (12). Singh, Armstrong, and Lipsky found that obesity, joint pain, and visual impairment prevented patients from running foot care independently (13). In this condition, the role of nurses in health centres and health volunteers is very important to teach families and patients about diabetic foot care. This is in line with the research conducted by Sari which stated that the patient's foot care behaviour increased after being given a family-based foot care education program for four weeks (14).

Foot Care training program for Health Center Nurses and health volunteers is carried out repeatedly accompanied by simulations and mentoring. Diabetes-Self Management Education (DSME) provides recommendations to improve self-management of Persons with DM. There for health, education process must be carried out continuously to gain the knowledge, skills, and abilities for Self Care Practice 
in diabetes care (15). The Foot Care training program for Health Center Nurses and health volunteers gave significant results, one of which was influenced by the level of education of the respondents, the results found in this study were 7 health centre educated in nurses (S1/Undergraduate + nurses) and from 23 health volunteers, 2 of them were educated in undergraduate, while 17 other people educated in high school.

The method used in educational programs plays a role in increasing the ability to perform nurses and health volunteers doing foot care. The method used when the training program in this study is a simulation and the media used is a module with clear and colourful images. A module that contains the behaviour of foot care accompanied by pictures as an educational medium will also increase the effectiveness of education in improving behaviour. According to Sudiharto [2007], providing informative and interesting training materials, as very strong support in providing training. An interesting foot care training media and presentation methods accompanied by simulations and demonstrations will enhance understanding and stimulate the enthusiasm of Nurses and health volunteers in following the entire process (16). Sae-Sia et al. reported that the use of modules during an effective health education session improved knowledge and good behaviour within a period of 5 weeks (17), while Vatankhah et al. took up to 6 months (18).

Respondents who were actively involved both during the training process and the mentoring process also contributed to the increasing ability of nurses and health volunteers to perform foot care. Respondents have the opportunity to ask questions and express their opinions during the discussion session. Communication between respondents and researchers can strengthen the final results of the foot care training program. The effectiveness of this program is due to the mentoring process in the II week to identifying things that have been done and have not been done related to diabetic foot care, as well as recalling the foot care training materials that have been given and in the III week an evaluation of foot care was carried out by observing the implementation of foot care by respondents and filled in the form. Sae-sia et al. reported that follow-up by phone three times could show significant results. Follow-up is very important to evaluate foot care behavior (17).

The items of questions that experienced much improvement were looking carefully at the toes; using towels after washing the feet; and checking the inside and outside of shoes and sandals, because each item was something new for the respondent, in the past they used to wash feet without seeing between toes and after washing feet usually dried using footcloths, and used to wear footwear without never check the inside and outside of the footwear. After knowing the benefits of these actions, there was a significant change in the ability to perform nurses and health volunteers regarding foot care.

\section{Conclusion and Suggestion}

From this study, it can be concluded that the foot care training program significantly increases the ability performing foot care on diabetes of Nurses and health volunteers in working are of Batua Health Center, Makassar. Thus, it is recommeded that nurses and health volunteers regularly providing health education related to foot care for diabetes patient to prevent foot ulcer such as including it in Prolanis health education program.

\section{References}

1. Chapman S. Foot care for people with diabetes: prevention of complications and treatment. $\mathrm{Br} \mathrm{J}$ Community Nurs. 2 Mei 2017;22(5):226-9.

2. Stanley M, Beare PG. Buku ajar keperawatan gerontik. Edisi 2. Jakarta: EGC; 2017.

3. International Diabetes Federation. IDF Diabetes Atlas. International Diabetes Federation. Edisi 7. International Diabetes Federation; 2015.

4. $\quad$ Price SA, M.Wilson L. Patofisiologi. Konsep klinis dan proses-proses penyakit. Edisi 6. Jakarta: EGC; 2012.

5. Yusuf S, Okuwa M, Irwan M, Rassa S, Laitung B, Thalib A, dkk. Prevalence and Risk Factor of Diabetic Foot Ulcers in a Regional Hospital, Eastern Indonesia. Open Journal of Nursing. 2016;06(01):1-10.

6. Schaper NC, Van Netten JJ, Apelqvist J, Lipsky BA, Bakker K, on behalf of the International Working Group on the Diabetic Foot (IWGDF). Prevention and management of foot problems in diabetes: a Summary Guidance for Daily Practice 2015, based on the IWGDF Guidance Documents: Prevention and Management of Foot Problems in Diabetes. Diabetes/Metabolism Research and Reviews. Januari 2016;32:7-15.

7. Bus SA, van Netten JJ, Lavery LA, Monteiro-Soares M, Rasmussen A, Jubiz Y, dkk. IWGDF guidance on the prevention of foot ulcers in at-risk patients with diabetes: IWGDF Guidance on the Prevention of Foot Ulcers. Diabetes/Metabolism Research and Reviews. Januari 2016;32:16-24. 
8. Sia WS, Maneewat K, Kurniawan T. EFFECT OF A SELF-MANAGEMENT SUPPORT PROGRAM ON DIABETIC FOOT CARE BEHAVIORS. International Journal of Research in Nursing. 1 Januari 2013;4(1):14-21.

9. Fan L, Sidani S, Cooper-Brathwaite A, Metcalfe K. Improving Foot Self-Care Knowledge, Self-Efficacy, and Behaviors in Patients With type 2 Diabetes at Low Risk for Foot Ulceration: A Pilot Study. Clinical Nursing Research. Desember 2014;23(6):627-43.

10. Lincoln N, Jeffcoate W, Ince P, Smith M, Radford K. Validation of a new measure of protective footcare behaviour: the Nottingham Assessment of Functional Footcare (NAFF). Practical Diabetes International. Mei 2007;24(4):207-11.

11. Abrar, Yusuf EA, Sjattar EL. Video Edukasi Perawatan Kaki DM. 2018.

12. Muhlisin A, Irdawati I. TEORI SELF CARE DARI OREM DAN PENDEKATAN DALAM PRAKTEK KEPERAWATAN. Berita Ilmu Keperawatan [Internet]. 1 April 2017 [dikutip 6 Desember 2019];2(2). Tersedia pada: http://journals.ums.ac.id/index.php/BIK/article/view/3800

13. Shahbazian H, Yazdanpanah L, Latifi SM. Risk assessment of patients with diabetes for foot ulcers according to risk classification consensus of international working group on diabetic foot (IWGDF). Pakistan Journal of Medical Sciences [Internet]. 30 April 2013 [dikutip 6 Desember 2019];29(3). Tersedia pada: http://pjms.com.pk/index.php/pjms/article/view/3473

14. Saleh NM, Shebl AM, Hatata ESZ, Refiei MR. Impact of Educational Program about Foot Care on Knowledge and Self Care Practice for Diabetic Older Adult Patients. Journal of American Science. 2012;8(12):1444-52.

15. Funnell MM, Anderson RM. Empowerment and Self-Management of Diabetes. Clinical Diabetes. 1 Juli 2004;22(3):123-7.

16. Black J, Hawks J. Medical Surgical Nursing: Clinical Management for Positive Outcomes. Elsevier; 2009.

17. Riset Kesehatan Dasar. Badan Penelitian dan Pengembangan Kesehatan Kementrian RI. Jakarta; 2013.

18. Štrajtenberger-Trbović M, Turk-Štrajtenberger V, Sekerija M. Standardized educational program in persons with type 2 diabetes on oral hypoglycemic therapy: Effects on glycemic control and body mass index. Diabetologia Croatica. 1 Januari 2011;40:35-40. 